\title{
Ritual space as borderland: building and breaching ritual borders in eastern central Gujarat
}

\author{
Gregory D. Alles (1D
}

\author{
Correspondence: \\ galles@mcdaniel.edu \\ Department of Religious Studies, \\ McDaniel College, Westminster, MD \\ 21157, USA
}

\begin{abstract}
This essay discusses the fundamental structure of ritual practice among the Rathvas, an adivasi group in Chhotaudepur district, Gujarat. It examines in some detail various sites of ritual practice to show how Rathvas imaginatively construct borders at these sites. At times Rathvas elaborate upon pre-existing natural or artificial borders, while at other times they construct a border where none existed previously; they do both in order to locate a place for devs, devis and ancestors. The essay then suggests that Rathvas construct these borders in order to breach them imaginatively and interact with devs, devis and ancestors via ritual practice. Elements within contemporary cognitive science, such as the notion of subconscious mental processing, the image schemata developed by Mark Johnson and utilized by George Lakoff, and analyses of theory of mind, can help to explain these practices. By contrast, a strong tradition in the study of religions that has focused upon sacred space does not. Rathva rituals occur at specific places, but they do not necessarily construct sacred spaces. In doing so, they are not unique.
\end{abstract}

Keywords: Borders, Borderlands, Chhotaudepur, Ind puja, Pithora, Rathvas, Ritual space, Sacred space

\section{Background}

My claim in this paper is that, to a significant degree, ritual among the Rathvas, a community of adivasis (indigenous people) who live in the easternmost portion of the western Indian state of Gujarat, proceeds by constructing and then breaching borders. I want to explore this claim partly because I want to gain a better understanding of Rathva rituals that I have myself experienced. I also want to explore it because it contrasts with familiar models of ritual and religious space, models that have become somewhat second nature to me and perhaps to others, too.

As is well known, Mircea Eliade, now much maligned, thought of sacred space as the establishment of a cosmos (Eliade 1959). There is in fact a good deal of empirical evidence for this view of sacred space in South Asia, starting with temple architecture. ${ }^{1}$ Jonathan Z. Smith, always willing to do a riff on Eliade, contrasted Eliade's "locative" view of sacred space, which he saw as conservative, with a "utopian" view more appropriate to progressive or revolutionary aspirations (Smith 1978: chap. 4; cf. Smith 2003: but note especially p. 23, fn. 9). Placed somewhere or nowhere, however, a sacred space

(c) The Author(s). 2017 Open Access This article is distributed under the terms of the Creative Commons Attribution 4.0 International License (http://creativecommons.org/licenses/by/4.0/), which permits unrestricted use, distribution, and reproduction in any medium, provided you give appropriate credit to the original author(s) and the source, provide a link to the Creative Commons license, and indicate if changes were made. 
is still an ordered space, inevitably bound to its inverse twin, chaos. Translated into narrative and systematic reflection, this emphasis expresses itself in a concern for cosmogony and cosmology (e.g., recently Lincoln 2012:31-62, 109-119).

When scholars focus on such ordered spaces, borders are often conceived of in a manner that, I think, ultimately derives from Émile Durkheim's emphasis on the categorical difference between the sacred and the profane (Durkheim, Emile 1965:52-56). They mark separation, the place where the profane ends and the sacred begins (e.g., Herrero de Jáuregui 2015). It is not that scholars of religions have been unaware of what Mary Louise Pratt has called "contact zones" (Pratt, Mary Louise 1991; cf. Clifford 1997), but they have tended to see them through the lens of the postcolonial political: as places where different peoples and cultures interact (Carrasco 2004; Chidester 2008). Even Thomas Tweed, who has made much of borders and boundaries, seems to conceive of borders as enclosing spaces - what he calls chronotopes of body, home, homeland, and cosmos - and defining boundaries that must be "crossed," whether corporeal, terrestrial, or cosmic (Tweed 2006:123-163).

I certainly do not want to dispute the usefulness of any of the above perspectives, but here I will not focus on borders as delimiters of the sacred and the profane or as limits of existence to be traversed. Instead, I will treat them as a locus of creative activity in their own right. As stated above, I want to focus on what I see as a fundamental dynamic of Rathva rituals: the construction of borders in order to breach them, which we may see as a kind of experimental creativity in maintaining life and redressing problems. In the end I will suggest that ideas from the cognitive sciences, such as the image schemata rooted in corporeal experience that Mark Johnson $(1987,2007)$ talks about (cf. also Lakoff 1987:271-275, 420, 453- 456), can help us understand this activity. Within the possibilities opened up by these and other cognitive processes, Rathva ritualists employ loosely defined scripts to interact with devs, devis and ancestors and so to acheive their goals. One consequence of this analysis may be unexpected: there is no reason to think that this ritual activity presupposes a fully conceptualized, bounded space, whether Eliade's cosmos or Tweed's chronotopes or some other. A border may be just an obstacle or impediment or hurdle along a well- or ill-defined path. In short, although Rathva rituals occur at specific places, they do not necessarily construct sacred spaces.

I need, however, to make two immediate qualifications to my opening claim, for it is both too narrow and too broad. First, I need to note that Rathvas are not the only adivasi group in the area where they live. Small numbers of Dhankas and Naykas live in some villages with them, although the publicly available census data does not allow us to quantify their respective populations village by village. Since these people often share ritual practices, the practices I refer to as Rathva may be shared by other adivasis as well. My primary experiences, however, are with Rathvas, and I am comfortable making claims only about them. Second, Rathva religious practice is more diverse than I will represent it as being here. This is primarily because over the last several decades various caste Hindu movements have been actively engaged in proselytizing in the area. Because Rathvas often see themselves as backwards and Hindu groups as more civilized - a view which proselytizing groups certainly encourage - they have been joining these groups in relatively large numbers. Locally, those who convert are known as bhagats. Two major issues of contention between bhagats and non-bhagats are eating meat and drinking alcohol; bhagats refrain from both. More to the point here, bhagat ritual practices are significantly different from those I will be discussing. 
They often involve presenting offerings and singing bhajan (religious songs) before massproduced images of a deity or guru - or a guru thought of as a deity - listening to religious talks, and perhaps reading devotional texts or listening to them and bhajan on a DVD or MP3 player. $^{2}$ These are challenges to which non-bhagat ritualists, unlike the Japanese Buddhist priests whom John Nelson (2013) talks about, have not yet begun to respond directly. While the general contours of my analysis may in fact extend to bhagat practices, that is a topic for another occasion. I am deliberately limiting myself here to the practices of nonbhagats, people known locally as jagats, nagats, or nungras and seen as being traditional adivasis.

\section{Building borders}

According to the 2011 Census, Rathvas (Rathawas) are the third largest adivasi community (Scheduled Tribe) in the Indian state of Gujarat, after Bhils and Dublas. About 79.6\% of Rathvas were concentrated in what in 2011 was Vadodara District. In 2013, however, Vadodara District was split in two, and the eastern half became the tribalmajority district of Chhotaudepur (Chhota Udaipur). Presumably most Rathvas live in what is now Chhotaudepur District, and in fact in the two easternmost talukas of that district, Chhotaudepur and Kavant talukas, but we will have to wait until the 2021 Census for actual statistics. Another $17 \%$ and $2 \%$ of Rathvas live in the contiguous districts of Panch Mahals and Dahod to the north, respectively. The remaining $1.4 \%$ are scattered in small numbers throughout all of the other districts in the state, the smallest number in 2011 being a single Rathva who was living in the Dangs. ${ }^{3}$ Some Rathvas also live across the border in Madhya Pradesh, but there they are generally counted as Bhilala. The majority of Rathvas remain non-literate. In 2011 general literacy among them was $44.4 \%$ (53.6\% for men, 35\% for women). This figure actually represents a significant improvement, especially for women, over 2001 , when general literacy was $36.8 \%$, male literacy $50.2 \%$, and female literacy only $22.8 \%{ }^{4}$ The vast majority of Rathvas (95\%) are rural, ${ }^{5}$ and they make their livings by tilling their own fields or, when necessary, manual labor. Men sometimes migrate seasonally to earn money by working as laborers in other parts of the state. Although agriculture is still small-scale and typically done with a single-furrow wooden plow pulled by two bullocks, mechanized farming is slowly making its appearance.

The name Rathva is sometimes said to derive from that of the Rath territory - an area that juts out of northeastern Chhotaudepur District into Madhya Pradesh. Many Rathvas consider this territory to be the place where Rathva culture exists in its purist form. It originally belonged to the princely state of Alirajpur (now in Madhya Pradesh), but in 1808 it was given to the princely state of Chhotaudepur as security in exchange for a loan (Ishai, Subhash: Tribal rituals and beliefs: a study with reference to the Pithoro festival of Rathva community in Gujarat: Report of a University Grants Commission Minor Research Project, 2013-2015, unpublished). It was never redeemed, and now, except for a tiny island of land in the middle of this area that is part of Madhya Pradesh (the village of Sajanpur), it belongs to the state of Gujarat (Census of India 2012:386).

Geographically, the Rathvistar comprises the relatively level, arable land on both sides of the Orsang River and its tributaries as it flows from the Madhya Pradesh border to Chhotaudepur town. The river makes a large arc, and the main road in the area, the Chhotaudepur-Alirajpur road (National Highway 56), runs roughly parallel to it. The plains are bordered on either side by large, uncultivable hills (or small mountains) that 
belong to the western extremity of the Vindhya Range. To the north they culminate at some distance in the Ratanmahal hills, and to the south they culminate at a much closer distance in scattered, individually named hills. Two of the hills to the south are especially significant ritually: the twin peaks of Babo Tundvo and Ay Tundvi in the eastern part of the area (only Babo Tundvo is used for worship) and the tall hill of Vaghasthal in the southwest, across the river from Chhotaudepur town. They are not the only large hills of religious significance to Rathvas; Koraj Hill, west of the Rathvistar in the area north of Tejgadh, also comes to mind (Tilche, Alice 2011), as does Pavagadh with its famous sanctuary of Kali. But they are the most important locally. ${ }^{6}$

Babo Tundvo and Vaghasthal demarcate the natural borders of the Rathvistar, but in adapting these hills for ritual use, Rathvas have added built structures that create a different kind of border from a geographical one. The added structures demarcate not the edge of a space but the course of a path leading up the hill. They occur at the beginning (the foot of the hill), the middle (about halfway up), and the end (the summit) of the path. Babo Tundvo is perhaps a better example of this adivasi ritual practice than Vaghasthal is. The latter, being closer to Chhotaudepur town, receives many more visitors, and it includes Muslim and Hindu shrines as well as adivasi ones.

The preeminent ritual locus at Babo Tundvo is on the summit. There one finds a large mound of terracotta objects, primarily terracotta horses one to three feet tall and structures known as dhaba, a foot or two in height, whose shape generally resembles a pith helmet or, perhaps a more appropriate analogy, a stupa, but with an entry hole in one side. These terracottas were previously presented to Babo Tundvo in rituals, and they are so pervasive in the area that it is immediately obvious that one is at a place of the devs and devis, in fact, given the immensity of the depository, a very important place. The figures are manufactured by non-adivasi potters, and although they are stylized, they show some variability and occasionally even creativity in the richest, most inventive sense of the word. Particularly striking on the summit of Babo Tundvo in 2009 were two finely decorated horses and riders, dedicated by a Rathva from a well-to-do family in the area when he set off to do masters level work at the University of Leeds. They have since succumbed to the forces of decay. ${ }^{7}$

In 2009 there were, at the very front of the depository, leaning against the terracotta figures, several wooden structures consisting of two thin vertical sticks, perhaps two and a half to three feet tall, connected by a similarly thin crossbar on which had been applied orange-red dots known as tipna. ${ }^{8}$ These are toran, gateways, but they are not gateways that permit entry into a sacred territory. Instead, the terracotta horses - the vehicles of the devs and devis - are set so that they face human visitors coming to the end of the steep path. They appear as if they are about to ride through the toran into our world. ${ }^{9}$ Thus, toran mark barriers, but they do so in a manner that has evocative imaginative overtones. As I shall suggest in more detail later, they invoke - preconsciously and kinesthetically - image schemata associated with inside and outside - notably, what Johnson and Lakoff refer to as the "container" image schema - to create the impression of a border between the human world and the world of the devs and devis. The significance of this border is marked ritually by, for example, small terracotta oil lamps lit and placed on top of small mounds of paddy in a line in front of the toran.

Something similar happens, but on a more modest scale, at the other two ritually marked points on the path up Babo Tundvo, the beginning and the middle. In 2009 
there was, at the foot of the hill, a small shrine containing a memorial stone, terracotta horses, dhaba, and remnants of other rituals at the foot of a tree. It, too, was marked with a miniature toran, ${ }^{10}$ but once again this is no toran that people walk through. It sits parallel to the path and constructs an imagined border between those walking on the path and the site where the ritual elements sit. In other words, it identifies the beginning of the path, and by implication the path itself, as a special contact zone rather than simply a path up a hill. ${ }^{11}$ It marks a place where humans encounter beings who inhabit the space on the other side of an imagined border. The ritual space halfway up the path is less developed. It consists simply of a leveled spot on the "saddle" between Babo Tundvo and Ay Tundvi that looks out over a drop-off at the jangal and hills in the distance. ${ }^{12}$ During neither my visits in 2009 nor my visit in 2017 was there a toran at this contact zone, and in 2009 there were no horses or dhaba, either. At that time the border resulted from the use made of the landscape: the drop-off (scalable without equipment but not without difficulty) which looks out onto open space. By 2017 the place was quite different. There was a cache of $d h a b a$, horses, and clay pots - remnants of prior observances - but vegetation had grown through them. The overlook was gone, and instead we "cut" our chicken at the foot of a tree on the opposite side of the saddle. This variation provides an opportunity for issuing a word of caution. One should not expect to find the precise forms that I found on Babo Tundvo replicated exactly anywhere else - or in fact in the future on Babo Tundvo. Instead, Rathvas put together structures from a repertoire of elements in accordance with certain general notions that they have about how such structures should be constructed. Other actual structures vary according to the shape of the space, the materials and financial resources at hand, the importance of the site, the preferences of the people erecting them, past local practice, and probably other factors as well.

Another striking manner in which Rathvas construct ritual borders is the artwork for which they are most known, Pithora paintings (Shah 1980; Jain 1984; Pandya 2004; Ishai 2008; Tilche 2015, 2011; Rathva and Rathva 2016). Traditional Rathva houses consist of a covered verandah, enclosed on three sides, behind which are the interior rooms: a kitchen and a sleeping area. The Pithora is painted on the outside of the wall that separates the verandah from the interior rooms. Except for the doorway to the interior, it occupies the entire space of the wall. Traditionally, a Pithora is painted as a result of a vow taken by the householder on the occasion of some misfortune, such as the illness of a child or barrenness of cattle. ${ }^{13}$ It is painted by a team of specialists known as lakhara ("writers") and then dedicated in an all-night ritual in the course of which a badvo, a ritual specialist, becomes possessed.

Like the structures that transform hills into ritual borderlands, Pithora paintings transform a pre-existing boundary, in this case the wall that separates the most interior, domestic space from a more public area of the household. Lakhara inscribe several features that transform the wall into an opening onto the world of the devs and devis, similar to the door that opens onto the interior of the house. Around the perimeter they paint a thick border, but it is clearly more than just a frame. At the bottom center is an opening, often surmounted by two guardian tigers with large grins who look straight out from the plane of the Pithora at its human viewers. This opening is a gateway to the world of the devs and devis, and occasionally lakhara portray it as a toran, similar to the toran on Babo Tundvo and elsewhere. The opening transforms the border into a fence or wall that separates the 
space of the Pithora not only from the rest of the two-dimensional space on which it is painted but also from the three-dimensional space in which those who are viewing it stand. A thread, hung from the top left to the top right corner, reinforces this effect. It is strung with dhebra (deep-fried lentil cakes, but thicker and not so big in diameter as dhebra commercially available in the U.S.) and other items such as betel nut and lemon. This thread, too, is said to be a toran. In the language of Johnson's image schemata, we encounter once again a boundary that separates an inside - our world - from an outside.

Pithoras are the most graphic Rathva representation of what lies on the other side of the borders that constitute ritual space. They take their name from the central depiction in the painting: at least five horses with riders, usually facing toward the left. These horses and riders are said to depict the wedding procession of the dev Pithoro, who oversees life in the domestic sphere. Figures in the painting depict a large number of other devs and devis as well, whether in human form, such as the devs and devis of destiny, animal form, such as the horses of the rains, or various hybrid forms, such as a twelve-headed figure sometimes identified with Ravana. The world of the Pithora, however, is also a world much like our own. It contains human figures engaged in activities from daily life - milking, fetching water from a well, collecting toddy from a toddy palm, plowing, even copulating - as well as ritual life: a badvo singing before a line of branches (on which see below), a group of dancers led by a man playing a dhol (a large drum) and other men playing sharnai (reed instruments). While the placement of the horses is fixed, lakhara have a certain amount of flexibility with regard to their number, color, and riders. The design and location of many of the other figures also permits variation, and the same is true of the design of the border. But however the rectangular border is executed, it is significantly more than a frame. It is taken to be the horizons of the world of the devs and devis, the border that separates their world from ours. The opening at its base, along with the strung toran (a reference to the toran at the entry to the bride's house at the wedding ceremony), provides a way for humans not to enter into that world themselves but to interact with its inhabitants.

So far we have encountered constructed borders, such as gateways, that are placed at actual borders (mountains, walls) and create an imaginative sense of a border of a different order, one that opens onto beings such as devs and devis. The toran on Babo Tundvo and the Pithoras do not create entrances that our bodies can actually utilize. Human beings cannot walk through walls, and even if one were small enough to crawl through the toran on the summit of Babo Tundvo, one's movement would be obstructed by the terracotta objects placed within them. Nevertheless, these structures call to mind the kinds of gateways through which human bodies do pass; perhaps they even evoke actional responses in what have come to be called mirror neurons. ${ }^{14}$ In any case, the point of these toran is not to create actual entrances. It is to create the impression of an entrance and, by implication, of a border across which one would move if one could and, as we will see, across which some movement is possible.

At times Rathvas do more than build borders that suggest entrances into the world of devs, devis and ancestors. They also construct entrances through which human bodies can move. A village devsthan ("dev place") is often simply a collection of artefacts set in a village borderland, that is, an untillable place such as a grove of trees, but once again, variation of design is common. A few devsthan, such as those at Ganthiya, Chathawada, Bedvi, and Singla were surrounded by walls of piled, unmortared stones when I visited them. At Chathavada, Bedvi, and Singla the entrance to the devsthan was simply an opening in the 
stone wall, but at Ganthiya it was marked with a life-sized toran similar in form to the toran on Babo Tundvo and elsewhere. Clearly, the wall demarcates a bounded sacred space or sanctuary that human bodies can enter. (In 2017, however, I was told that the primary purpose of the wall was practical: it keeps cattle and other larger animals out and so prevents them from destroying various objects found there.) As wealth and Hinduization are increasing, even more elaborate structures may be emerging. For example, in late 2014 a square, mortared brick structure with a tin-metal roof, still unplastered in January 2015 - a temple of sorts - was built around a pillar of Baliyarmata in the very large devsthan at Dhamodi. ${ }^{15}$

Within devsthan, even walled ones, Rathva ritual constructs other borders through which human beings cannot pass. One way it does so is by placing a thick crossbeam across two stout posts, perhaps two and a half feet tall, embedded into the ground. This is a common figure, but some examples are more striking than others. A particularly striking one can be found on the ledge halfway up Vaghasthal. When I visited it in 2009, 2012, and 2013, it was painted with vibrant colors - green, red, white - and fitted out with unusually elaborate terracotta figures: horses, both with and without riders, an elephant, and at times other imaginative creatures, placed so that they seem to be riding through the structure toward the worshiper. At the much more remote devsthan of Bedvi three sets of posts without crossbeams are placed in line with one another after this structure, creating a well-defined path for the vehicles of the devs to use. A badvo once told me that the posts with crossbeams were the seats of the devs and devis, but most people seem to think of them as the devs' darvaja, that is, as doors or gates through which devs and devis enter our world.

More common in devsthan than darvaja are khunta, stout pillars with flat tops that are embedded into the ground (cf. Stiglmayr 1963). Each khunto is associated with a specific dev, although actually identifying them may tax the memories of ordinary people. ${ }^{16}$ Khunta are often carved from teak wood, and their cross-sections may be hexagonal, octagonal, or circular. Their top six inches or so are usually separated from the rest of the shaft by a deep notch and at times by a different cross-sectional design as well. Sometimes they are painted, as were the vivid green khunta with red and white highlights newly dedicated at Chathawada at the end of April 2009, but most often they are stained a deep, dull red. Very occasionally, they present opportunities for creative artists. For example, the post dedicated to Baliyarmata in the devsthan at Chathawada was carved in the form of a woman wearing green clothing, a red shawl, and silver jewelry, standing at attention on the back of a tiger painted yellow with black stripes. ${ }^{17}$ Since the khunta stand exposed to the weather for years, their color gradually fades. By 2013 the vivid colors of the Chathawada khunta, Baliyarmata included, were sadly becoming only memories.

Khunta are generally surrounded by terracotta figures: horses, sometimes with riders, and $d h a b a$, and occasionally elephants or tigers. As we have already observed, these figures vary in size and design; those at the new devsthan at Chathawada were particularly large and artistically fashioned. Khunta do not, however, define borders as two-dimensional planes, the way toran, Pithoras, and darvaja do. They are basically one-dimensional vertical lines, like giant stakes, although this is not an analogy that I have ever heard Rathvas use. They define a place where a $d e v$ is present or can be invoked. In that sense, they are like boundary stones or markers. The erection of a khunto creates a point at which the human world and a dev can meet. 
Khunta are a common sight in devsthan. Indeed, most devsthan are simply collections of khunta and perhaps a darvajo, arranged geometrically or haphazardly, with terracotta figures at their bases but without any border. Other ritual uses of posts rely more heavily on pre-existent borders. One is the khatris, the shrine to the ancestors. It consists of a line of khunta located at the edge of a field, occasionally in a stand of trees. Without the khunta, this edge of the field would just mark the end of a cultivable piece of land. The addition of the khunta transforms it into a borderland where humans and their ancestors can meet. A second important place where a post creates a borderland is within the house, most often in the kitchen. Here stands a single post, either against a wall or in a corner. It marks the place as one where, once again, the family can encounter its ancestors.

What we have seen so far is this: Rathvas make ritual places by "borrowing" physical borders and transforming them imaginatively for ritual purposes. These physical borders include the hills that form the borders of the Rathvistar, the house walls on which Pithoras are painted, the groves or other untillable areas where devsthan are located, the edges of fields where khatris are placed, and walls or corners, usually of kitchens, where the house posts sit. There is, however, one prominent instance in Rathva ritual when a border is constructed where no prior border existed. This occurs in a celebration known as Ind puja, the worship of the dev Indraj.

Ind puja takes place in the middle of a flat, fallow field (cf. Alles 2015). It honors Indraj, the maternal uncle of Pithoro and the dev of fields and forests. The element of Ind puja that concerns us most at the moment is the construction of the ritual place. A number of branches, about six to ten feet long, are cut from a kalam tree. (Sometimes branches from the kalo tree are used.) These branches are "planted," perhaps along with sugarcane stalks, in holes dug in a straight line in the middle of the field. They define an upright, two-dimensional plane that creates a wall where none had previously existed. On the ground in front of the branches are placed straight lines of patla (low benches for various devs and devis), matla (pots), oil lamps, and various other ritual accoutrements for use in puja. The "wall" of the branches thus becomes more than just a newly constructed physical barrier. It serves as a barrier that opens onto the world of the devs and devis - a kind of shuttered window, if you will, in contrast to the open window of the Pithora. Within 24 hours, once it has fulfilled its ritual purpose, it is dismantled and the branches are deposited in a body of water, preferably a river.

Let us summarize what we have said up to this point. A crucial part of Rathva rituals is the building of borders that suggest a juncture between the space we ordinarily inhabit and the world of devs, devis and ancestors. In many cases these borders employ elements of the natural landscape (hills, groves) or the built environment (walls, borders of fields). When they do, they supplement them with elements (toran accompanied by terracotta horses and dhaba, Pithora paintings, khunta) that carry culturally specific meanings related to devs, devis and ancestors. In at least one other case, however, Rathvas ritually construct a border where none existed previously. This is in Ind puja, when they erect a line of branches in the middle of a fallow field and place different items in front of it - patla (miniature benches), matla (pots), and so on - that also make cultural reference to the devs, devis and ancestors. Certain parameters, cognitive and cultural, define the basic patterns to which these constructions adhere, but in following the patterns considerable variation is possible, limited by several factors: local geography, materials at hand, financial resources, aesthetic 
preferences, a desire for innovation or replication, local purposes, and so on. One factor that does not yet seem much to have entered into play is a desire to compete with the various proselytizing caste Hindu movements that have entered the area. There is, however, at least one indication that changes inspired by caste Hinduism, whether motivated by a desire to compete or not, may be in the offing. I am thinking of the temple for Baliyarmata constructed in 2014 in the devsthan at Dhamodi.

\section{Breaching borders}

As is already evident from the construction of toran and darvaja, the building of borders is not an end in itself. It is the preparatory part of the ritual. The ultimate goal is to breach the borders that have been evoked in the imagination. Such a breach enables Rathvas to interact imaginatively with devs, devis and ancestors. It does so because the borders, by representing their separation from these beings, spatialize and localize them and so facilitate contact with them.

The space available here does not allow for a detailed consideration of all of the rituals that Rathvas perform at the borders we have identified. Such a detailed consideration is not, however, necessary to advance my argument, the general contours of which look like this: The (imagined) efficacy of Rathva rituals derives from their ability to breach artificially constructed borders, but the borders are not fully porous. They do not enable complete bi-directional movement. Only certain kinds of movement across them are possible. Specifically, living human beings cannot go across to the other side, and physical objects from the other side cannot come across to the human side. What crosses the borders are, from the human side, various gifts that human beings present and, from the other side, the devs and devis themselves.

As we have already seen, within certain limits the settings of Rathva rituals permit a good deal of variation. The performances do, too. Elsewhere, in a discussion of a kind of Ind puja known as Gamshahi, I have suggested that Rathva rituals are constructed from a repertoire of widely used routines along with a few ritually specific scripts (Alles 2015). ${ }^{18}$ These routines and scripts are only loosely fixed action programs, and they vary considerably from person to person and with the occasion. For example, the series of actions performed in sacrificing a chicken will include some basic steps and elements, and some of these steps are constrained by the logic of action. One cannot put a lamp on top of a pile of paddy unless one has first made a pile of paddy. One cannot tie a thread strung with dhebra to a khunto unless one has first strung the thread with dhebra. Otherwise, however, there is considerable variation in terms of the order in which actions are performed as well as in the materials employed, depending upon the preferences of the person performing the ritual and the availability of elements. Does one tie a thread on which dhebra have been strung to a khunto before or after one makes a pile of paddy and places a lamp on it? Are these two separate action blocks or can they be intermingled, first stringing the dhebra on the thread and making a pile of paddy (or vice versa) and then tying the thread to the khunto and placing the lamp on the rice (or vice versa).

Similarly, the mantras and gayna (bhajan, songs) that are recited during Rathva rituals also permit variation. I recently received a good illustration of this from Subhash Ishai (Department of English, S.N. College, Chhotaudepur). In early 2015 in the village of Od (Chhotaudepur taluka), he recorded a gaynu that referred to Babo Pithoro studying at 
Bhasha Kendra, that is, at the Adivasi Academy in Tejgadh. This is clearly a motif added relatively recently. The Adivasi Academy was founded only in the late 1990s and its facilities were constructed in the early 2000s. But whether in action programs or in recitations, such variation is hardly unexpected. There have been no authoritative mechanisms to fix the details of Rathva ritual practice, as there have been in other traditions, non-literate as well as literate. Given such variability, we can consider here the kinds of general patterns that appear in ritual practice, without worrying excessively about how they are combined in any particular ritual performance.

Perhaps the most common set of routines, performed by specialists and non-specialists alike, is puja. It consists of placing a variety of objects at a ritually constructed border and presenting them to a target dev or ancestor. The central offering is the presentation of food items, among which dhebra, kodri (cooked red rice), coconut pieces, and the livers of sacrificed animals (chickens, goats, or both) are the most common. These items are often laid out on leaves of the bili tree and placed on the ground or the floor (made of cow-dung plaster) at the foot of the constructed border. In addition, it is customary to pour out streams of mahua liquor near the leaves, but not onto them. If the puja involves the offering of an animal's liver, the animal is killed in a specific way as part of the ceremony: water is poured on its head and mantras are recited until it shakes its head, indicating its willingness to be killed. It is then decapitated, ideally with a single stroke, and its dead body is carefully placed before the constructed border. A small incision is made in its side, and the liver is removed, cooked, cut into pieces, and placed on leaves for presentation at the border. Special attention is paid to the decapitated head. For example, when animals are sacrificed before a Pithora, the severed stump of the neck is daubed against the opening in the border, leaving it stained with blood.

These elements may suffice for a smaller ritual, although even the small puja that I observed at the saddle on Babo Tundvo in March 2009 added to them incense and a single lighted lamp, placed on a small pile of paddy. Major rituals involve the presentation of a large number of other elements. For example, at a celebration of Ind puja one may find, in addition to leaves with foodstuffs and mahua bottles, the following elements - and more - placed before the branches: several piles of paddy, each surmounted by a lighted oil lamp; patla (low bench-like structures) on which rest husked rice, dhebra, and lighted oil lamps; patla on which rest woven bamboo baskets with sprouts of seeds that were ritually planted nine days earlier; matla containing grain or other ritually important substances, topped with a leaf that is tied down around the neck of the pot with a thread that is strung with several dhebra; a sword stuck point first into the ground around whose shaft has been tied a thread strung with dhebra and a lemon; several coconuts; a sickle; pots of water; baskets of kodri; lighted incense; and roasted maize. In addition, rupee coins are placed in the holes when the branches are planted and possibly under the small mounds of paddy. Many of these elements, such as the patla, matla, mahua bottles, and the ground underneath the paddy, will be marked with orange-red dots known as tipna while they are being dedicated, and they may also be greeted with arati. The elements placed at khunta are somewhat different. Here one finds, in addition to terracotta horses, dhaba, and perhaps an elephant or tiger, mounds of paddy surmounted by lighted oil lamps, coconuts, incense, and money.

The placement of these objects at the borders is done carefully and with a sense for their visual appearance. Surely this is part of their appeal. But it would be wrong to see them as simply constituting a beautiful display. They are part of an imaginative construction 
that invokes social norms of gift-giving governing relations between persons. Precisely how the process works seems not to matter much. The physical elements are somehow thought to cross the constructed border and reach the appropriate dev or ancestor, who feels duly pleased by the gifts. This is the explicit general purpose of all such ritual behavior. The physical objects are then imagined as gifts received that signal the devs and devis' pleasure.

Other types of ritual activity at the constructed borders generally require specialists, above all, a badvo and his assistants. Badva have the ability to discern which situations require which rituals for their redress, and they either perform or instruct others on how to perform traditional ceremonies. Above all, however, they are experts in communication across the borders. On the one hand, they have what amounts to a monopoly on the mantras and gayna to be used in ritual contexts, and for all practical purposes on the stories that underlie them. On the other, they have the ability to receive devs and devis into their own bodies, so that they may speak and act in our world.

When I say that badva have a virtual monopoly on mantras and gayna, I do not mean that ordinary householders cannot recite mantras, for example, when making offerings and performing sacrifices in front of their houseposts. They can and do. Generally, however, householders readily admit that they do not know the proper mantras. In cases when they do not hire a badvo, they recite the names of as many devs, devis and ancestors as they can remember hearing badva use in the past, improvise, and hope that the devs, devis or ancestors will understand. From the most common Rathva perspective, however, only badva know the proper mantras to use in addressing devs, devis and ancestors. (Opinions differ on precisely how much knowledge each badvo has.) Their gayna recall events such as the creation of the earth, the origin of the rain, and the generations leading up to Indraj, his sister Kali Koyal, and her son Pithoro. ${ }^{19}$ During rituals badva recite mantras and sing gayna, but they do not do so for the benefit of human onlookers; given the circumstances of recitation, their words and songs are often unintelligible to bystanders, especially at large festivals, where there is a great deal of ambient noise. Instead, they sit in front of the borders and direct their mantras and gayna across them. In doing so, they suggest the presence of beings who are otherwise undetectable, the devs, devis and ancestors.

Badva are not just experts in communication directed toward the devs, devis and ancestors; they are also specialists in communication coming from them. At certain points in specific rituals, notably, before the branches of Ind puja and before the Pithora, while a badvo is singing his gayna, his limbs begin to shake, he throws off his turban, and he begins to "dhune," that is, to shake his head vigorously up and down. ${ }^{20}$ This behavior is taken as a sign that a dev has entered the badvo's body. The dev indicates its presence by whooping, dancing, and holding consultations for selected persons. During the dedication of the Pithora painting, the devs and devis themselves comment on whether their world has been properly depicted or not. As has often been observed about possession, the effect is not unlike theater - the badvo gives the imaginative impression of being a different person, and within limits different badva seem to have their own personal routines - but the local interpretation is different. It is thought that in this manner devs and devis are able to cross the ritual borders and appear in bodily form among human beings.

Badva are not the only people who facilitate this form of communication. For example, late in the morning and early in the afternoon on Thursdays, a small number of women gather at Vaghasthal and become possessed. I have only observed this behavior 
at the Hindu temple and Muslim dargah at the foot of the hill, but I have been told that it also occurs at the vibrantly painted darvajo on the ledge halfway up the hill. This possession behavior, however, is judged differently than the possession of a badvo - or someone receiving a call to become a badvo. It may be acceptable for a householder to make rough attempts at reciting mantras and singing gayna, but it is a violation of social norms for a non-badvo to become possessed. In fact, many Rathvas, perhaps the majority, consider persons who receive the devs and devis in this way, mostly women, to be witches (dakan). I know of no cases in which women who do become possessed in this manner have been murdered on charges of witchcraft - other cases of witchcraft murder are occasionally reported - but most Rathvas choose to avoid their practices.

In sum, by ritually breaching constructed borders, Rathvas imaginatively interact with devs, devis and ancestors. Although embodied human beings cannot themselves breach these borders physically, they can engage in behavior that kinesthetically and preconsciously suggests a crossing of the borders by invoking normal patterns of social interaction, namely, giving gifts, especially food and drink, to imagined beings and addressing them with words. Similarly, although objects from the devs, devis and ancestors cannot cross the borders into our world (even if consecrated food is somehow considered to be a gift from the devs and devis), the devs and devis themselves can seem to enter into human bodies. This happens when a person's bodily actions and speech suggest the presence of a different personality. As with the building of ritual borders, the breaching of borders provides opportunities for variation and invention within broad limits. Nonetheless, the gifts, mantras, gayna, and possession behavior all carry culturally specific prompts that frame the breaching of ritual borders in terms of interaction with devs, devis and ancestors.

\section{More generally}

My basic contentions, then, are as follows. A significant aspect of Rathva ritual practice consists of building borders and then breaching them. These are borders and breaches of the imagination. (Note that imaginative is not necessarily imaginary; I do not mean for this statement to make any claim about reality.) In building borders, Rathvas suggestively alter pre-existing natural borders (mountains, groves) or constructed ones (walls, borders of fields) or construct borders where none existed (Ind puja branches). When they do so, they fit out the borders with accoutrements that, within Rathva culture, signal the presence of devs, devis and ancestors: terracotta horses and dhaba, patla, and so on. Then they engage in actions that suggest the breaching of those borders. They present gifts at the borders, most notably foodstuffs and liquor, and "receive" gifts in return; they address the borders with mantras and sing gayna before them; and people - normatively, religious specialists (badva) - speak and act in such a way as to suggest that their own agency has been replaced by that of devs, devis and ancestors.

In this final section I want to set these claims in a more general context by making three observations. First, I want to note that this building and breaching of borders is not unique to Rathva ritual; it is, in fact, quite common, even in globalizing digital modernity. Second, I want to tie together some observations made in the course of the preceding discussion by suggesting that certain ideas in contemporary cognitive science can help explain this building and breaching of borders. In doing so, I will rely heavily but not exclusively on the image schemata identified by Mark Johnson and George 
Lakoff. Finally, I want to draw out the implications of this analysis for the way scholars of religions have often approached the analysis of space. Specifically, as mentioned earlier, I want to point out that a focus on building and breaching borders may not entail the concerns with sacred space that many scholars of religions have come to take for granted.

The building and breaching of imaginative borders is hardly unique to the Rathvas and their ritual. It is, in fact, widely familiar in contemporary modernity. We encounter it in a long line of imaginative depictions that includes, among many other examples, the rabbit hole in Lewis Carroll's Alice, H. G. Wells' The Time Machine, the tesseracts in Madeleine L'Engel's A Wrinkle in Time and the Marvel comics movie "The Avengers," Platform 9-3/4 at King's Cross Station in the Harry Potter series, and the link between two universes in Christopher Nolan's science fiction film, "Interstellar." It may take a 3D film like Alfonso Cuarón's "Gravity," where elements appear to float in the space of the movie theater itself, to remind us that this experience of building and breaching borders is much more widespread than explicit depictions of portals between two realms. Visually, it includes every depiction of another place on the screen of a cinema, television, or computing device. Even closer to the Rathva structures that I have been discussing were the structures erected during the Bergen (Norway) Wood Festival in May 2012. The theme was "The Portal," and various teams competed in constructing portals out of wood. Some "borrowed" a pre-existing structure, such as a drain or the path defined by a road between two lines of buildings. Others constructed freestanding portals in previously empty space (except for the pavement). Unlike the case with Rathva ritual borders, there were no cultural prompts suggesting anything that we might consider religious, except perhaps in the case of the portal entitled "Tree of Life." However, religious uses of portals have not been unknown outside the Rathvistar as well. For examples we need look no further than trompe l'oeil paintings in various churches that represent the heavenly realm.

In other words, the ability to detect portals and connections across them between our world and an imaginative one is quite widespread. One set of questions that this ability raises is cognitive. What allows us to look at these borders in this way? While I cannot claim to offer a full explanation, here are some bits and pieces that may help.

In a best-selling book, the Nobel-prize winning psychologist, Daniel Kahneman, distinguishes between two mental systems. He writes, "System 1 is gullible and biased to believe, System 2 is in charge of doubting and unbelieving ... but System 2 is ... often lazy. Indeed, there is evidence that people are more likely to be influenced by empty persuasive messages, such as commercials, when they are tired and depleted" (Kahneman 2011:81). ${ }^{21}$ There is a problem with this formulation. While conscious processing - Kahneman's System 2 - may be handled by a single mental system, subconscious processing almost certainly is not (e.g., Evans 2008; Stanovich 2004). There is no "System 1;" instead, there are a multitude of systems that function subconsciously with varying interactions between them. But Kahneman's observation does suggest where to look for explanations as to why the Rathvas' building and breaching of ritual borders works at an intellectual level - and perhaps why, for example, the badvo's "channeling" of devs and devis occurs in the middle of the night or early morning under conditions of sleep deprivation.

For an account of the mechanisms involved, one could do worse than start with Mark Johnson's work on embodied meaning. ${ }^{22}$ It is not necessary for us to engage here 
Johnson's philosophical claims about objectivism and "the conceptual-propositional theory of meaning" (Johnson 2007: 8-10). As a non-philosopher I hesitate to make pronouncements about such matters, but I sometimes wonder whether Johnson and those he criticizes are actually talking past one another. ${ }^{23}$ I think, however, that there is value, especially for understanding the building and breaching of borders in Rathva rituals, in Johnson's observation that "our experience of meaning is based, first, on our sensorimotor experience, our feelings, and our visceral connections to our world; and, second, on various imaginative capacities for using sensorimotor processes to understand abstract concepts." In a manner reminiscent of the dual-processing model of mental activity, Johnson claims that much of this experience is preconscious. "Sometimes our meanings are conceptually and propositionally coded," he writes, "but that is merely the more conscious, selective dimension of a vast, continuous process of immanent meanings that involve structures, patterns, qualities, feelings, and emotions."

In his book, The Body in the Mind (1987), Johnson introduces the notion of an "image schema" derived from bodily experience. Such a schema is a pattern that necessarily cannot be represented as an actual image - what Johnson calls a "rich image" - or a proposition but nevertheless is a pattern that we use to make sense of the world (Johnson 1987:23-28; cf. Lakoff 1987:271-275, 420, 453-456). In his view, "[i]mage schemata exist at a level of generality and abstraction that allows them to serve repeatedly as identifying patterns in an indefinitely large number of experiences, perceptions, and image formations for objects or events that are similarly structured in the relevant ways" (Johnson 1987:28). In a later book he writes, “... image schemas are precisely [the] basic structures of sensorimotor experience by which we encounter a world that we can understand and act within. An image schema is a dynamic, recurring pattern of organism-environment interactions" (Johnson 2007:136). ${ }^{24}$

To the extent that this view is correct, several of Johnson's image schemata would seem to be involved in the Rathva construction of ritual borders. Perhaps the most obvious is the schema of the container, defined by an interior, a boundary, and an exterior (Johnson 2007: 138, 141). The experience of such containers, Johnson says, is intrinsic to our experience of both our bodies and their movement through space. It also provides fundamental metaphors by which more abstract thought understands the world. One could suggest that when we encounter structures like those we have been talking about - toran, darvaja, Pithoras, devsthan, the branches in Ind puja, even khunta and houseposts as boundary markers - we reflexively apply the image schema of the container to them. As Johnson notes, building on work by Daniel Stern, "We crave the emotional satisfaction that comes from pattern completion, and witnessing even a portion of the pattern is enough to set our affect contours in motion" (Johnson 2007:144). He even suggests a neurophysiological correlate for this reaction: the parts of the pattern that we observe set our mirror neurons in motion. ${ }^{25}$ As a result, we perceive the various ritual structures as borders that mark a transition from the inside to the outside. But what do they separate from what? Cultural knowledge associated with the artefacts present at the borders serves to point this reflexive sense in a particular direction, in the case of the Rathvas, the direction of the devs, devis and ancestors. As we have seen, such cultural knowledge permits of considerable variation and innovation, but that, too, is consistent with the notion of image schemata being general patterns that apply to a variety of experiences. ${ }^{26}$ 
This account is, of course, too quick and easy to be a complete explanation of the mental processes involved in Rathva constructions of ritual borderlands. For one thing, other image schemata would seem to be relevant. One of them is the schema of source-path-goal, which is capable of being blended with the schema of container (Johnson 2007:137-138, 141-142). It is most explicitly present on hills such as Babo Tundvo and Vaghasthal. We experience the paths up these hills, preconsciously and kinesthetically, as having destinations, but what is the destination? One could climb them simply for the views; indeed, I have enjoyed the views from both summits with Rathva friends. But placing gateways on the summit suggests something more: that the summit defines a boundary beyond which the path continues. Terracotta horses apparently ride along the path in the opposite direction and suggest what lies beyond: the realm of the devs and devis. Another set of image schemata are clearly relevant to the paths up Babo Tundvo and Vagasthal. These are schemata associated with verticality, such as up/down and over, widely familiar in the study of religions through terms such as axis mundi and transcendence (Johnson 2007:137; Lakoff 1987:416-461). Apart from the hills, however, such schemata are not widely triggered by Rathva ritual structures, even khunta, since all but the smallest children will look down upon them. If it is appropriate to talk about transcendence in the Rathva context at all, it is a transcendence that is horizontal, not vertical (cf. Alles 2017).

To the extent that the building of imaginative borders depends upon such image schemata as in/out, paths, and up/down, their breaching does, too. For example, the ritual use of toran seems to presuppose the experience of the body actually moving through a gateway, even if such movement is not generally possible in Rathva rituals. But the breaching of the borders would also seem to trigger other cognitive mechanisms, rooted in some of our most basic experiences as social animals. In performing puja Rathvas offer highly valued food and drink: the liver of animals and mahua liquor. ${ }^{27}$ They also offer gifts. To be meaningful, both acts require an intentional recipient, even if no actual recipient can be perceived by the senses. The same is true of reciting mantras and singing gayna for someone else's entertainment. The means used to suggest crossing the border from the other side - human embodiment of the devs and devis - invoke different mechanisms. As Emma Cohen (2007) has pointed out, such possession phenomena make use of the mechanisms of "theory of mind," which attributes mental activity to the people we encounter and does so in a way that is intrinsic to our sense of their identities. When the badvo dhunes and begins to act in ways that we do not ordinarily associate with him, we may experience this as play acting, but we may also experience it as a different mind in control of the body and suggest that a temporary shift of identity has occurred. Cultural clues provide insight into what - or rather, who - this identity might be.

All of these explanatory hints require more elaboration than is possible here. It would also be worthwhile to raise the question of generalization: to what extent are these processes common in what English speakers often call religion? I want to close, however, with brief comments that tend in a different direction. I want to emphasize a corollary of the hints that I have made.

Under the influence of writers like Mircea Eliade, and perhaps also under the influence of a general existentialist orientation that sought to understand religion in terms of the creation of a meaningful world, scholars of religions have been accustomed to think of the creation of a sacred, ordered space as crucial to religion. On this view, one 
might see religiously defined space as primary and ritual borders as derivative. None of the mechanisms that I have identified, however, requires this to be the case. Consider the image schema of the container. One can have a sense that one has gone from an inside to an outside without having to specify - or being able to specify - in any detail what the features of the inside or the outside are. The sense of crossing a border may in fact motivate a person to think more reflectively about how space on the two sides of the border is structured, or it may not. The same is true for the uses I have identified for Johnson's image schemata of path and up/down, for social patterns associated with feeding, giving drink, and entertaining, and for the identification of persons in terms of minds. As I put it earlier, Rathva rituals occur in specific places, but they do not require sacred spaces.

Despite the prevalence of talk about sacred space within the study of religions over the last half century and more, I can imagine extensions of these comments well beyond the Rathvistar to ritual practice in a large variety of traditions. ${ }^{28}$ For example, the building and breaching of borders might well characterize both Hindu puja and the Christian Eucharist, neither of which seem to me to require a great deal of cosmological clarity to be effective (as seen from the inside). "Theologians" in these traditions have, of course, formulated very sophisticated cosmological views, but as a recent trend has strongly emphasized, religious practitioners are not always - and perhaps not always - theologically correct (cf. Slone 2004), nor in fact are they always interested in theological niceties. Furthermore, I suspect that the breaching of perceived borders is not at all limited to ritual activity; one could also characterize many practices that we are accustomed to call mystical this way. ${ }^{29}$

At the same time, I do not mean to claim that religions never conceptualize sacred space. I would even be reluctant to claim that the experience of borders is always primary and the conceptualization of sacred spaces is always derivative, motivated by a desire to make intellectual sense of the borders one has experienced. I do intend to claim, however, that it is possible to participate meaningfully in rituals performed at ritual borderlands without having a clear, clean, conceptually coherent account of the worlds that sit on either side of the border. This, I would venture, seems to be the case with most of the Rathvas I know and have met. They show little knowledge of or interest in whatever cosmologies and cosmogonies may inform local expert opinion. In this lack of knowledge and interest I do not think that they are alone. At the same time, the Hindu dharmic traditions that are entering the area do come with full-blown accounts of such matters, and they teach them quite explicitly. This may be one reason why Rathvas who have become bhagat, especially those who have received a formal education, have found them appealing.

\section{Endnotes}

${ }^{1}$ I am thinking above all of talk about the temple as cosmos as, e.g., in George Michell's classic text, The Hindu Temple (1977). I might also point out that the pattern is not limited to South Asia. In October 2016, almost a year after the text of this paper was completed, I visited the Jiba, the place in Tenri, Japan, where, according to Tenrikyo, God the Parent first created human beings. Prof. Yoshitsugu Sawai (Tenri University) gave a detailed explanation of the entire complex, after which either he or Prof. Anis Malik 
Thoha (Sultan Agung Islamic University, Indonesia) observed, quite properly, that the conception of the whole complex was thoroughly Eliadean.

${ }^{2}$ For examples, see https://www.facebook.com/pragatpurushottamchhotaudepur (last accessed 3 May 2017) and other Pragat Purushottam sites on Facebook.

${ }^{3}$ Computed from Census of India 2011, Table A-11 (Appendix) District Wise Scheduled Tribe Population (for Each Tribe Separately), available online at http://www.censusindia. gov.in/2011census/PCA/SC_ST/PCA-A11_Appendix/ST-24-PCA-A11-APPENDIX.xlsx, accessed 3 May 2017.

${ }^{4}$ Census of India 2011, Table A-11 State Primary Census Abstract for Individual Scheduled Tribes, available online at http://www.censusindia.gov.in/2011census/PCA/SC_ST/ PCA-A11_Appendix/ST-24-PCA-A11-APPENDIX.xlsx, accessed 3 May 2017; and Census of India 2001, "Gujarat: Data Highlights: The Scheduled Tribes," available online at http:// censusindia.gov.in/Tables_Published/SCST/dh_st_gujarat.pdf, last accessed 3 May 2017.

${ }^{5}$ Villages in Chhotaudepur taluka range in population from 6545 (Tejgadh) to 41 (Juna Udepur), with an average population of 1497. Villages in Kavant taluka range from 5835 (Kanalva) to 224 (Deri), with an average population of 1530. The only two urban areas in these talukas are Chhotaudepur town (population 25,787) and Kavant town (population 9,553). See Census of India 2011, Primary Census Abstract Data Tables for Gujarat, available online at http://censusindia.gov.in/pca/pcadata/Houselisting-housingGujarat.html, accessed 3 May 2017. One should note that in this region "village" generally denotes a non-nucleated area. For a more general description of the region and the people, see Ratnagar 2010.

${ }^{6}$ Brief accounts of various hills are found in Rathva 2016: 99-101.

${ }^{7}$ My account of Babo Tundvo is based on observations made in March and April 2009 and January 2017. The article itself, however, was completed in the fall of 2015, so in order not to interrupt the flow of the narrative, I have mostly included observations from 2017 in the endnotes. That changes took place is not unexpected, but because my principal aim here is to discuss basic ritual structures, they do not alter the analysis.

${ }^{8}$ Tipna are placed on objects during the recitation of mantras. Each tipna represents a dev invoked. Remnants of earlier toran are thrown onto the pile with the remnants of earlier offerings.

${ }^{9}$ By 2017 the toran from 2009 had disappeared, and other toran, made from stouter wood but still short, stood behind an impressive line of clay horses.

${ }^{10}$ By 2017this site, too, had changed, but not its status as a ritual place. The toran was gone. Ritual attention had shifted to the tree behind the earlier upright stone, which was marked with a series of tipna. A red thread was tied around its trunk, and several thin wooden poles, surmounted by orange flags, leaned against it. A stone, similar in shape to the memorial stone and covered with tipna (perhaps it was the same stone), was now lying flat on the ground in front of the tree along a line parallel to the path. It was flanked on either side by many small $d h a b a$ and horses, and in front of it was a small charred area where we offered the livers of the chickens that we had killed on the summit of the hill.

${ }^{11}$ In using the word "special" I have in mind Taves 2009.

${ }^{12}$ Worship centers on Babo Tundvo rather than Ay Tundvi because, I have been told, it is not possible to reach the summit of Ay Tundvi.

${ }^{13}$ Here, too, there are exceptions. On 11-12 January 2017 I visited the Gamshahi celebration in the village of Raipur (Kavant taluka). Somewhat unusually for a Gamshahi, 
the village also dedicated a Pithora in the house of the Patel. When I asked what had occasioned the painting of the Pithora, I was told that no particular illness or misfortune had resulted in the Patel taking a Pithora vow. The village had just decided it wanted a communal Pithora, and the Patel's house seemed the best place to have it painted.

${ }^{14}$ Technically mirror neurons may only concern the processing of observed behavior on the part of other beings rather than static structures, and mirror neuron theory is not without its critics. On mirror neurons, cf., among many other sources, Gallese et al. 1996, Rizzolatti et al. 1996; for critique, Hickok 2014.

${ }^{15}$ Personal communication, with photographs, from Subhash Ishai January 6, 2015.

${ }^{16}$ On 18 January 2016 the village of Singla rebuilt its devsthan and took an unprecedented step in dealing with this challenge to memory: it erected written signs identifying the various devs and devis, and did so despite the fact that, according to the 2011 Census, only $36.4 \%$ of the village population was registered as literate. A month later, on the 17th of February, the village of Vanar rebuilt its devsthan. The names of the various devs were painted directly on the khunta because, I was told, it is often difficult to remember what names the badvo has given to them. According to the 2011 Census, slightly under $25 \%$ of the population of Vanar was literate, but the rebuilding was taken in part at the initiative of the family of a science and maths teacher who holds office in the taluka-wide teachers association.

${ }^{17} \mathrm{My}$ impression is that the carving was done by Ghulsingbhai Rathva of Ganthiya, now unfortunately deceased. Illness prevented me from attending the dedication ceremonies.

${ }^{18}$ The earliest European ethnographers to visit the Rath area, Josef Haekel and Ernst Stiglmayr, seem to have taken this feature as signaling a lack of imagination and genuine religious experience; cf. Haekel, and Stiglmayr 1961: 39. As I shall suggest, a different view is possible.

${ }^{19}$ For a brief summary of the Rathva "Story [kathā] of the gods' in Rathvi and Gujarati, see Rathva 2016: 53-60.

${ }^{20}$ On this English transformation of the Gujarati verb dhunvum, see Hardiman 1987.

${ }^{21}$ Scholars of religion might recognize this distinction from talk of "theological incorrectness;" cf., e.g., Slone 2004.

${ }^{22}$ For different applications in religious studies, see, e.g., Slingerland 2008, Taves 2009, Vásquez 2011, and, in a more focused analysis, Herrero de Jáuregui 2015.

${ }^{23}$ For example, when Johnson redefines meaning and emotion, are he and the objectivists still really talking about the same things?

${ }^{24}$ See Johnson 2007: 144-145 for a summary account of image schemas. For a partial list of image schemata, see Johnson 1987: 126.

${ }^{25}$ To be more precise, Johnson 2007: 142-143, 161-162 suggests a possible neurophysiological explanation in terms of "mirror neurons," "constrained' connectionism," and "topologic neural maps." In the case at hand, perceiving a gateway would stimulate in the brain neurons involved in moving through the gateway - although in the absence of specific neurophysiological evidence, this statement remains speculative.

${ }^{26}$ On the role of the cultural, cf. Johnson 2007: 152: "Meaning requires a functioning brain, in a living body that engages its environments-environments that are social and cultural, as well as physical and biological." 
${ }^{27} \mathrm{Cf}$. Greek sacrifices, where the gods receive the parts least valuable to human beings, famously explained by the trickery of Prometheus; cf. Hesiod Theogony 535-557.

${ }^{28}$ This is a point which Laurie Patton made when an earlier version of this essay was presented at the 2012 annual meeting of DANAM.

${ }^{29}$ I owe this suggestion to Antoinette DeNapoli.

\section{Acknowledgements}

Earlier versions of this essay were presented at the annual conference of the European Association for the Study of Religion in Södertörn, Sweden in August 2012 and the annual meeting of the Dharma Association of North America (DANAM) in Chicago in November 2012. I am grateful for the comments received there. Thanks are due, as always, to the people in Chhotaudepur taluka without whose assistance and toleration this essay would not have been possible. I must especially acknowledge here Bahubhai Harijan (Moti Sadhli), Subhash Ishai (Chhotaudepur), Arjun Rathva (Moti Sadhli), Ashvinbhai Rathva (Kanalva), Dashrath Rathva (Kocvad), Desing Rathva (Rangpur), Haribhai Rathva (Malaja), Kocar Rathva (Gabadiya), Madhu Rathva (Vanar), Mansing Rathva (Malaja), and Paresh Rathva (Kavant), who, in introducing me to Rathva ritual borders, helped me to cross cultural ones. I must also express my thanks to Dr. Alice Tilche, then a doctoral student at SOAS, with whom I visited many sites and from whose insights I have benefited. Thanks are due, too, to the Bhasha Research and Publication Centre, Vadodara, and the Adivasi Academy, Tejgadh, for repeated hospitality, and once again to Subhash Ishai, with whom I have discussed all of these topics and many more in detail; he has kindly read through the manuscript with a fine-toothed comb and corrected at least some of my mistakes. Fieldwork in India has been generously supported by the U.S. Fulbright Program (2009), the Faculty Development Committee of McDaniel College, Westminster, MD, and the research program Indigenous Religion(s): Local Grounds, Global Networks, at the University of Tromsø, supported by funds from the Norwegian Research Council.

\section{Publisher's Note}

Springer Nature remains neutral with regard to jurisdictional claims in published maps and institutional affiliations.

Received: 31 October 2016 Accepted: 21 April 2017

Published online: 13 July 2017

References

Alles, Gregory D. 2015. Work and play in Gamshahi: performing the indigenous village in eastern Gujarat. International Quarterly for Asian Studies/Asienforum 46(1-2): 103-125.

Alles, Gregory D. 2017. Hints of ontology in eastern Gujarat: structures of space in Rathva cultural practices. In Marginalised and endangered worldviews: comparative studies on contemporary Eurasia, India and South America, ed. Lidia Guzy and James Kapalo. Berlin: LIT Verlag. Ethnologie: Forschung und Wissenschaft, 26.

Carrasco, David. 2004. Jaguar Christians in the contact zone: concealed narratives in the histories of religions in the Americas. In Beyond primitivism: indigenous religious traditions and modernity, ed. Jacob K. Olupona, 128-138. London: Routledge.

Census of India. 2012. Administrative Atlas: Gujarat. New Delhi: Office of the Registrar General and Census Commissioner.

Chidester, David. 2008. Dreaming in the contact zone: Zulu dreams, visions, and religion in nineteenth-century South Africa. Journal of the American Academy of Religion 76(1): 27-53. doi:10.1093/jaarel/lfm094.

Clifford, James. 1997. Museums as contact zones. In Routes: travel and translation in the late twentieth century, 188-219. Cambridge: Harvard University Press.

Cohen, Emma. 2007. The mind possessed: the cognition of spirit possession in an Afro-Brazilian religious tradition. Oxford: Oxford University Press.

Durkheim, Emile. 1965. The elementary forms of the religious life. Trans. Joseph Ward Swain. New York: Free Press.

Eliade, Mircea. 1959. The sacred and the profane: the nature of religion. New York: Harcourt, Brace \& World.

Evans, Jonathan St B.T. 2008. Dual-processing accounts of reasoning, judgment, and social cognition. Annual Review of Psychology 59: 255-278.

Gallese, Vittorio, Luciano Fadiga, Leonardo Fogassi, and Giacomo Rizzolatti. 1996. Action recognition in the premotor cortex. Brain 119(2): 593-609.

Haekel, Josef, and Engelbert Stiglmayr. 1961. Bericht über die österreichische zentralindien-expedition 1960/61. Wiener Völkerkundliche Mitteilungen, n.s 11(4): 25-44.

Hardiman, David. 1987. The coming of the Devi: Adivasi assertion in western India. Delhi: Oxford University Press

Herrero de Jáuregui, Miguel. 2015. The construction of inner religious space in wandering religion of classical Greece. Numen 62: 5-6.

Hickok, Gregory. 2014. The myth of mirror neurons: the real neuroscience of communication and cognition. New York: W. W. Norton.

Ishai, Subhash. 2008. Bābo Pițhoro. Ādilok 1(1): 10-11.

Jain, Jyotindra. 1984. Painted myths of creation: art and ritual of an Indian tribe. New Delhi: Lalit Kala Akademi.

Johnson, Mark. 1987. The body in the mind: the bodily basis of meaning, imagination, and reason. Chicago: University of Chicago Press.

Johnson, Mark. 2007. The meaning of the body: aesthetics of human understanding. Chicago: University of Chicago Press. Kahneman, Daniel. 2011. Thinking fast and slow. New York: Farrar, Straus and Giroux.

Lakoff, George. 1987. Womem, fire, and dangerous things: what categories reveal about the mind. Chicago: University of Chicago Press. 
Lincoln, Bruce. 2012. Gods and demons, priests and scholars: critical explorations in the history of religions. Chicago: University of Chicago Press.

Michell, George. 1977. The Hindu temple: an introduction to its meaning and forms. New York: Harpet and Row.

Nelson, John K. 2013. Experimental Buddhism: innovation and activism in contemporary Japan. Honolulu: University of Hawai i Press.

Pandya, Vishvajit. 2004. Rathwa Pithoro: writing about writing and reading painted ethnography. Visual Anthropology 17: 117-161.

Pratt, Mary Louise. 1991. Arts of the contact zone. Profession:33-40. doi:10.2307/25595469.

Rathva, Naran. 2016. Rāțhava samāj. In Choțāudepur jillānā ādivāsī samājono sāṃskrtik ane mānavaśästrīya abhyās, ed. Kanji Patel, 3-60, 91-123, 153-174, 193-267, 297-298, 305-310. Vadodara, India: Bhasha Research and Publication Center.

Rathva, Naran, and Vikesh Rathva. 2016. Bhäratìya ädim citrakalā: Rāțhavā samājamām Bābopịțhoro. Vadodara, India: Bhasha Research and Publication Center.

Ratnagar, Shereen. 2010. Being tribal. Delhi: Primus Books.

Rizzolatti, Giacomo, Luciano Fadiga, Vittorio Gallese, and Leonardo Fogassi. 1996. Premotor cortex and the recognition of motor actions. Cognitive Brain Research 3: 131-141.

Shah, Haku. 1980. The ritual painting of the god Pithora Baba: a tribal ritual in central Gujarat. Ethnologische Zeitschrift Zürich 11: 7-62.

Slingerland, Edward. 2008. What science offers the humanities: integrating body and culture. Cambridge: Cambridge University Press.

Slone, D. Jason. 2004. Theological incorrectness: why religious people believe what they shouldn't. Oxford: Oxford University Press.

Smith, Jonathan Z. 1978. Map is not terriroy: studies in the history of religions. Leiden: Brill.

Smith, Jonathan Z. 2003. Here, there, and anywhere. In Prayer, magic, and the stars in the ancient and late antique world, ed. Scott B. Noegel, Walker Joel Thomas, and Brannon M. Wheeler, 21-36. University Park: Pennsylvania State University Press.

Stanovich, Keith. 2004. The robot's rebellion: finding meaning in the age of Darwin. Chicago: University of Chicago Press. Stiglmayr, Engelbert. 1963. Die Kultpfähle der Rathwa-Bhilala. In Festschrift Paul Schebesta zum 75. Geburtstag, gewidmet von Mitbrüdern, Freuden und Schülern, Studia Instituti Anthropos 18, 371-380. Vienna: St. Gabriel-Verlag.

Taves, Ann. 2009. Religious experience reconsidered: a building block approach to the study of religion and other special things. Princeton, N.J.: Princeton University Press.

Tilche, Alice. 2011. In search of an Adivasi worldview: identity, development and the Adivasi museum of voice in western India. Ph.D. dissertation, School of Oriental and African Studies. London: University of London.

Tilche, Alice. 2015. Pithora in the time of kings, elephants and art dealers: art and social change in western India. Visual Anthropology 28: 1-20.

Tweed, Thomas A. 2006. Crossing and dwelling: a theory of religion. Cambridge, Mass.: Harvard University Press.

Vásquez, Manuel A. 2011. More than belief: a materialist theory of religion. Oxford: Oxford University Press.

\section{Submit your manuscript to a SpringerOpen ${ }^{\circ}$ journal and benefit from:}

- Convenient online submission

- Rigorous peer review

- Immediate publication on acceptance

- Open access: articles freely available online

- High visibility within the field

- Retaining the copyright to your article

Submit your next manuscript at $>$ springeropen.com 